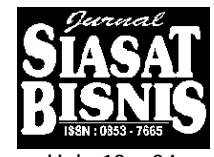

Hal.: $13-24$

\title{
A MARKETER'S POINT OF VIEWS: STRATEGY OF DEVELOPING AND REINFORCING BRAND LOYALTY IN THE 1990'S*)
}

\author{
Anas Hidayat \\ Universitas Islam Indonesia
}

\begin{abstract}
The rapid change in competition and technology results in decrease in brand loyalty and business decline. This means that keeping customer loyalty is a very challenging effort today because brand loyalty is very important to acquire, maintain, and develop market share. To keep customer loyal to a certain brand or to keep a brand valuable in front of the customers' eye, marketer must be able to reduce marketing cost, to maintain trade leverage, to attract new customers, and to provide time to respond to competitive trade. Strategies that support to gain and retain the loyalty of today's consumers are understanding the customers, keeping brand image consistent, running promotion that develop loyalty, maintaining high standards of customer service, and soliciting retailer participation. Nevertheless, even for the company who has strong brand, reinforcing brand loyalty is still needed. There are seven factors that will relate to build brand loyalty reinforcement.
\end{abstract}

Key words: customer or brand loyalty.

\section{INTRODUCTION}

In the last two decades, companies found themselves competing in a race where the road signs and rules keep changing. Today's companies work in a war zone of rapidly changing competitors and technology advances. As a consequence of their changing business environment, most companies have met an apparent decrease in brand loyalty and suffer business decline. Consequently, today's companies must urgently and critically rethink their marketing strategy (Kotler, 1994).

From the marketing strategy viewpoint, because there are today's low growth, highly competitive market places, and diminishing customer loyalty to ward brands, brand loyalty becomes a very important concept for survival. Thus, brand loyalty is a challenging goal each marketer seeks to attain (Loudon \& Della Bitta 1993). This paper presents a strategy for attracting customers to ward brand loyalty in the 1990's.

\section{ON OVERVIEW OF BRAND LOYALTY}

Two approaches to the study of brand loyalty have dominated marketing literature. The first, an instrumental conditioning approach, views consistent with purchasing of one brand over time is an indication of brand loyalty. Repeat purchasing behavior is assumed to reflect reinforcement

*) Jurnal Siasat Bisnis Edisi Th. I Vol. 3, Nopember 1996 
and is a strong stimulus to respond. The second approach to the study of brand loyally is based on cognitive theories. This approach believes that behavior alone does not reflect brand loyalty. An attitudinal measure combined with a behavioral measure is required to identify true loyalty (Assael 1992).

Based on these two approaches, some researchers have suggested a useful definition of brand loyalty that recognizes that true brand loyal customers should exhibit not only a high degree of repeat purchasing but also a favorable attitude toward the purchase (Loudon \& Della Bitta 1993, p. 565).

In addition, brand loyalty is directly influenced by the consumer's satisfaction/dissatisfaction with the brand that has accumulated over time. Evidence also indicates that it is influenced by perceptions of the product quality (Mowen 1995).

As a result of brand loyalty, companies can attain or improve their market share. Hence, brand loyalty becomes a topic of much concern to all marketers (Exter 1986). Research suggests that an increase of market share is related to improved brand loyalty (Loudon \& Bitta 1993). In addition, the larger the number of loyal customers, the more stable the brand's market share, and the less vulnerable it will be to competitive efforts (Robinson 1979). Jacoby and Chestnut (1978) also state that all forms of repeat purchase behavior including brand loyalty are relative to developing, maintaining and protecting market share. Thus, companies that improve their market positions have to be successful both in getting brand users and an increasing in their loyalty (Paj 1985).

In practice, despite research recognizes that overall brand loyalty had been shown to be virtually stable over the 1970's (Johnson 1984), in the 1990's many individual brands have had an apparent decline loyalty (Loudon \& Della Bitta 1993). Julie Liesse, senior reporter with Advertising Age in Chicago, states that Brand loyalty may never again be what it was (quoted by Caudron 1993). Howeyer, Frank Johnson, Senior Vice President of Association Grocier Seattle, says that brand loyalty is not dead, nor will it die, but it certainly is in poor health (quoted by Winstein 1993).

Actually, the decline in brand loyalty is not limited to packaged goods, however, it occurs across the market place, in areas diverse as automobiles computers, fast food, and long-distance telephone services (Caudron 1993). For example, see table 1, in the case of American Automobile industry, even if American brands retain he loyalty they had during the 1980s, they will continue to suffer substantial losses in market share during the 1990s, because Japanese brands have much greater loyalty (Mannering \& Winston 1991).

Further, consumers are giving up their reliance on established companies and experimenting with lesser-known brands. For instance, a 
study conducted by Computer World Magazine indicated that $36 \%$ of sites that currently use IBM personal computers expect they will be looking for a new PC vendor (quoted by Caudron 1993). Hence, this situation is challenging for marketers remedying a decline in brand loyalty.

Loudon \& Della Bitta (1993, p. 564), furthermore, indicated that a decline in customers loyalty toward brands in the recent decade can be attributed in several factors these induce: (1) Sophisticated advertising appeals and heavy media support, (2) Parity of product in form, content, and communication, (3) Price competition from private and generic labels, (4) Sales promotion tactics of mass displays, coupons, and specials that appeal to customers impulse buying, (5) General fickleness of customers buying behaviors, (6) High inflation in the late 1970s and early 1980s, and (7) Growth of new products competing for shelf space and consumer attention.

Table 1. Forecasts of Changes in Cas and Light Truck Market Shares during The 1990s Percentage point change by brand

\begin{tabular}{|lcccc|}
\hline Manufacturer & 1989 share & $\begin{array}{c}\text { Scenario 1 } \\
\text { change during } \\
\text { the 1990s }\end{array}$ & $\begin{array}{c}\text { Scenario 2 } \\
\text { change during } \\
\text { the 1990s }\end{array}$ & $\begin{array}{c}\text { Scenario 3 } \\
\text { change during } \\
\text { the 1990s }\end{array}$ \\
General Motors & 35,1 & -4.20 & -3.26 & -3.14 \\
Ford & 24.6 & -3.20 & -2.76 & -2.15 \\
Chryster & 13.8 & -3.40 & -3.18 & -2.40 \\
Nissan & 4.6 & +2.50 & +2.05 & +1.72 \\
Honda & 5.4 & +2.72 & +2.20 & +1.79 \\
Toyota & 6.5 & +3.18 & +2.41 & +1.95 \\
\hline
\end{tabular}

Source: Mannering \& Winston, 1991, "Brand Loyalty and the Decline of American Automobile Firms", Brooking Institution, California

\section{STRATEGY VALUE OF BRAND LOYALTY}

The brand loyalty of existing customers represents a strategic asset that has the potential to provide value in several ways. According to Aaker (1991, p. 47), if properly managed and exploited, the values of brand loyalty are (1) reduced marketing cost, (2) trade leverage, (3) attracting new customers: brand awareness created and reassurance to new customers, and (4) providing time to respond to competitive trade.

With regard to trade leverage, brand loyalty seems to provide it. In relation to reduced marketing costs, companies that have customer loyal toward their brands will reduce the marketing costs of doing business. Having brand loyalty, it is simpler to retain existing customers than to get new ones. Based on estimation, it costs the average company six times more to attract a new customer than to retain an existing one (Peter \& Olsonn 
1990). This is because potential new customers are usually lacking motivation and not making an effort to change from their current brands or to locate brand alternatives. In addition, loyalty of existing customers represents a substantial entry barrier to competitors. Entering a market in which existing customers are loyal can require expensive to persuade them. On the other hand, existing customers are usually relatively easy to keep if they are not happy, which results in far less cost to hold them by limiting the reasons to change (Aaker 1991).

Tide loyalty to ward brands such Marlboro, Coca Cola, and Nescafe (Chernatony 1993) will ensure preferred shelf space because stores recognize that customers will have such brands on their shopping list. In other words, brand loyalty may dominate store choice decisions. When trade leverage has been established, it is easier for companies to introduce new sizes, varieties, or extensions to their brands (Aaker 1991).

In accordance with attracting new customers, companies that have relatively large satisfied customer bases provide an image of the brand as one that is accepted. Brand awareness can also be generated from the customer bases. Existing customers eil enhance recognition merely by being there. Friends and colleagues of users will become a ware of the product by seeing i. Seeing a product being used by a friend will generated he kind of memory link to the use context and to the user that any advertisement would have difficulty in doing so. Thus, brand recall will be stronger. In selecting the target market, one consideration should be their potential to create visibility and awareness for the brand (Aaker 1991).

Finalty, brand loyalty provides firms with time to respond to competitive threats. If competitors develop superior products, loyal customer will allow the firm time needed for the product improvements to be matched. For example, satisfied customers may not be looking for new products, and may not learn of advancement, even through there are many newly developed high-tech offering in the market. With a high level of brand loyalty, firms can allow them selves the luxury of pursuing a less risky follower strategy (Aaker 1991).

\section{STRATEGY OF BUILDING BRAND LOYALTY}

In the 1990's established brands face challenges that range from private-label products to deep-discount stores. Their managers must keep up with rapid changes in the way products are distributed, priced, and sold at the retail level. Brand manager's most important goals are to protect the brand's good name (Crispell \& Brandenberg 1993), and to cultivate the brand's loyalty (Eisman 1990). This is because brand loyalty is related to developing, maintaining, and protecting market share (Mannering \& Winston 1990). 
The key ingredients in gaining and retaining the loyalty of today's consumers are (1) understanding the customers; (2) keeping brand image consistent; (3) running promotion that develop loyalty; (4) maintaining high standards of customer service; and (5) colisiting retailer participation (Eisman 1990); and (6) making a satisfactory product (Walters \& Bergiel 1989).

In relation to understanding the customers, companies need to understand how customer loyalty has changed over time. Consumers generally fall into one of three groups consisting of consumers who buy mainly one brand; those who buy from among two or three brands; and those who purchase whatever is on sale. These consumer types will exist, but the balance is changing as the number of people in the second group grows. John Lister, an executive Vice President of Lister Butler, a Brand Identity Consulting Firm in New York, agrees that consumers are still loyal, but they area loyal to a larger number of brands (quoted by Eismen 1990). Therefore, some companies look at this as a promotional challenge hat focuses on consumers who switch among several brands, because they are likely to be better targeting for promotion.

In promoting, managers must let the consumers know that they have a good product, and this can only be done by effective promotion. On the other hand, consumers need to know that there are products worth of their loyalty. Consumers must be induced to try these products, and the initial trial must be reinforced until buying becomes automatic (Walters \& Bergiel 1989).

In addition, a brand it self has many features, and consumers tend to evaluate the benefits of these features independently. According to research, the most familiar of all brands is Campbell's Tomato Soup in America. Research found that when customers see a can of Campbell's Tomato Soup, the react in ways that are rational, emotional, and cultural Rationally, the customers think of tangible product qualities and features, such the price of soup. Then, the customers' emotional sides summons up a memory of the warm, comfortable feeling soup gives them. Finally, cultural influence makes customers consider the way they will be perceived by those who see Campbell's on their pantry shelf (Crispell \& Brandenberg 1993).

In order for reach a good rapport and to understand customers' evaluation of the brand features, companies may have to use qualitative research on their customers, or use focus groups and one on interviews, which in turn, will determine the effectiveness of the promotion. Those companies, who are continually cognizant of the customer's desires and are always a ware of what is going on in the marketplace, are the companies who are going to get the customers (Eisman 1990).

Furthermore, Donna Finley, a Vice President and Senior Account Executive at QLM Marketing Promotion, New York, says that in the 1990's, 
there is a trend to "new traditionalist," a person who is up to date in his approach but still embraces traditional value and is not too trendy (quoted by Eisman 1990). To appeal to these consumers, companies might want to stress their brand' heritage in promotions, citing an example companies that have been running their print ads from the 1930's side by side with current ads (Eisman 1990).

With regard to keeping brand image consistent, companies must be concerned with how consumers perceive their brand's image. Perhaps, this is the most important ingredient of brand loyalty, because the key to loyalty is that the image of the brand is clearly defined. Thus, everything the manufacturers do have to reinforce that image (Weinstein 1993). The product's quality image is affected by the packaging, distribution, advertising, and promotion (Kotler 1994).

In addition, part of today's image-building is being mindful of "integrated marketing." The American Association of Advertising Agencies states hat integrated marketing is where we believe the agencies business will be in the 1990's. Integrated marketing is important for reaching the consistency of the brand image (quoted by Eisman 1990). For example of this type of marketing can be found at Labbatt's USA, which has used 'the blueheaven theme" in many of its consumer promotions and retail displays to back up its Labbat's Blue Beer (Eisman 1990).

In running promotions that develop loyalty, a study recently released by the Promotion Marketing Association of America found that price promotions have a major impact on which product consumers by. However, not everybody believes that price promotions are the answer to customer loyalty to ward brands (Eisman 1990).

Companies that use promotion agree that best methods for building loyalty is the frequent buyer program, which allows consumers to accumulate points or dollars that can later be redeemed for various goods. Some advantages of these programs are (1) it is likely that customers will make repeat purchases in order to get a valuable award; (2) offering rewards for purchases "make the consumers feel good about making that purchase; and (3) Consumers will be more a ware of price than they used to be. Increasingly, companies are using electronic databases and "Smart Cards" to make these programs more effective. Cash register scanners and plastic cards with scan bars feed data on customer purchases into a computer, making it simpler for a company to track buying habits (Eisman 1990).

For example, recently, more than 100 manufacturers have participated in Reward America, a frequent program launched by Citicorp POS Information Service, Stamford, Conn, in October 1989. Consumers sign up at a participating supermarket and receive a Reward America card bearing 
a scan bar. The retailer stocks brochures explaining the manufacturers' offers, which are for savings on multiple purchases, and also puts up banners, point purchase displays and shelf talkers. When the customers make a purchase, the cards record it, and Citicorp processes the data and sends a statement to the customers each month. The saving are accumulated for gift certificates that can be used for purchases in any member store (Eisman 1990).

In addition, companies can run a frequent program without using electronic technology. For instance the Camden has been running a frequent buyer program with Label for Education. This encourages repeat purchase and hence brand loyalty. Another way, companies build loyalty through promotions is by targeting customers at important periods. For example, American Telephone and Telegraph targets consumer's at specific times to reach people when they are still at junior high and high school students. The pack contains coupons and product samples from several major consumers product firms (Eisman 1990).

In order to maintain high standards of customer's service, Gary Gerd, a Director of Customer Loyalty Systems for the Carlson Learning Company, a Division of the Carlson Companies states that Superior customer service is paramount. Every employee has to know his/her role in delivering that brand $t$ the customer (quoted by Eisman 1990). However, many employees do not realize that they play a large part in maintaining customer loyalty. Providing frequency programs is good for getting customers in, and once customers are there, other things customers in, and once customers are there, other things have to be done to get them to stay (Eisman 1990). Hence, a large part of the program focuses on how providing superior service influences consumer perceptions of the brand. All employees must realize that loyalty usually begins with the sale and the way the product is sold.

In soliciting retailer participation, the manufactures need dealer cooperation because the product has to be in the market place. If customers reach for the product, and it is not there, it is obviously a serious challenge to brand loyalty. The practice of using slotting allowances, the charge from the retailer to the manufacturer for getting the production the shelf, is on the rise in the grocery trade: Even though, many suppliers do not like these charges, suppliers need to buy the retailer's cooperation for getting brand loyalty (Eisman 1990). However, a really strong brand should not always have to do that.

Furthermore, many companies feel that even if they have a solid foothold in the market place they need to ensure that loyalty remains high through the right promotion mix. A strong brand has to keep going and be active in the competitive market by providing better promotion in terms of 
reinforcing brand loyalty. For example, Nabisco recently run a promotion for its Oreo brand, which hardly needs the publicity (Eisman 1990). Ben and Jerry's Ice Cream provides offensive promotion through many forms of media including newspapers, television, and radio; and also through many social activities such community events like Newport Folk Festival, the new Museum of America Folk, and various charity concerts (Pierce \& Robinson 1994).

Further, to get brand loyalty, management must also provide a satisfactory product, not only to customers, but to all groups in the environment that affect the firm. According to Walters and Bergiel (1989, p. 510), a satisfactory product is one that is profitable to the firm, wanted by consumers, legal, competitive, socially acceptable, and efficient in resource use. Despite, these companies recognize that providing the product is very difficult, therefore companies should al least keep these six objectives in mind every time they introduce a new idea, produce a product, and promote a product. The closer to the ideal management we come, the greater the like hood of success.

\section{STRATEGY OF REINFORCING BRAND LOYALTY}

If between customers and brands there is rapport, and customers tend to be loyal towards a brand, companies need to maintain a climate for loyalty, otherwise, companies will lose their brand loyalty. Yet, facing the competitive marketplace in he 1990's, based on research, customer of the 1990's have become much more savvy and price conscious (Caudron 1993). Today's promotion tends to be non-proprietary; a lot of companies end up copying each other (Eisman 1990). Therefore, Anil Jagtiany, a partner of Marketing Corp. of America, comments (quoted by Sellers, 1993): "Welcome to doing business in the brutal new world of brand."

In the turbulent competitive businesses today, research shows that while some brands are obviously more dominant than others, there is no such thing as a single brand. Hence, companies that have strong brand loyalty must continuously defend their current businesses against rival attack. For example, Coca Cola must constantly guard against Pepsi Cola; Gillette against Bic; and Hertz against A vis (Kotler 1994).

In every product field, there is a spectrum along which differently configured brands compete for customer's attention. For example, American Express and Barclycard are equally effective as a means of paying statement that it makes, and others chose Barcycard because it is accepted by a greater number of outlets (Chernatony 1993).

Research examines seven types of brand reinforcing which are available to business. The first is functional capability. The PIMS Database 
at the Strategic Planning Institute shows that there is strong correlation between profitability and quality. Power brands offer consumers the assurance of consistent high quality. Kellogg's commitment to quality has now been recognized by several generations of customers. The company's standards have been maintained in an era when customers have become increasingly bombarded with retailers' own brands. As a consequence, Kellogg's has kept its customer goodwill. Mars and Cadbury have also been scrupulous about protecting their taste heritage. By carrying over their product taste, they have been able to extend the brands into the ice cream bar and liqueur markets (Chernatony 1993). The 'Cadical' firm offers only a superior product and excellent service (Kotler 1994).

Further, Some managers think that quality is a competitive weapon. For example, Japanese companies learned long ago how consumers use clues to assess the quality of cars; they then focused on these points. As a result, for example, by the mid 1990's Japanese car production capacity continued to grow in America. While the Japanese are building plants, America companies are closing them. This happened because American car firms have suffered from higher price and lower quality than their Japanese counterparts (Mannering \& Winston 1991). Some businesses have succeeded in redfining the rules of competitive engagement based on quality. Caterpillar through its dealers network offers to service its own earthmoving equipment anywhere in the world within 36 hour. As a consequence, Comatsu found it difficult to compete on these terms (Chernatony 1993).

Second is symbolism. The emotional element associated with a product can make a significant contribution to the health of any brand. Choide is influenced not only by what the brand does for the consumers, but also by what it says about the consumer. Some managers with conspicuously consumed brands have been able to capitalize on their consumers. There are any number of brands that have had symbolic roles deliberately written in, through careful advertising and packaging (Chernatony 1993).

The importance of a symbolic component is best illustrated by comparing the Porche Carrera and Toyota Supra Turbo. Both cars are designed with closely comparable performance characteristics. Both accelerated from zero to $60 \mathrm{mph}$ in 6.1 seconds of around $150 \mathrm{mph}$, but the Porche image meant it was able to charge a premium price (Chernatony 1993).

Third is the name of the brand. At the turn of the century this was the key to the success of a brand, as the name and logo were at that time used to make better quality offerings stand out from the rest. However, a good name only is no longer enough today Hence, Finding a good name is 
no easy task. The name must not only seek the convery the brand's current strengths, it must allow for the possibility for extension into new area. In a sense, Caterpillar tractor proved a more adaptable name. The company was able to drop the tractor' when embarking on a brand extension program (Chernatony, 1993).

Fourth is sign of ownership. Where an organization has as a high public profile there are obvious advantages in linking the brand closely with the name of the parent company. Cannon, Phillips, and Cadbury are just there of the thousand of business which stamp their name on the their brand. In addition, retailer' own brand lean heavily on sign of ownership. Taking advantages of their closeness to consumers, several major multiple retailers have fine-tuned their brand to match consumers, needs. Their proposition is that quality is at least as good as the leading manufacturer's brand, but at lower price (Chernatony 1993).

The fifth is shorthand notation. In an era of increasing choice consumers are bombarded with vast amounts of information about competing brands. When consumers are presented with a full array of information about competing brands, the piece of information they are most attentive to-regarded as the besar indicator of performance is the brand name. Consumers use brand names to interrogate their long-term memory about brand characteristics. If the message that comes back is favorable, a purchase is likely to be made. Hence, Mars win by associating their brand names with a few key attributes and they simplify choice by using uncluttered package design on which the brand name stands out (Chernatony 1993).

The sixth is a strategic direction. Brands are most likely to succeed to strengthen them further. Strategic direction gives a brand the ability to out perform competitors. In board terms, customers perceive value in brand (1) when they cost less competing brand offering similar benefits, in they are cost driven; or (2) when they possess unique benefits, is they are value added brands. The Mazda 626 GLX Executive is a good example of a cost driven brand. All aspects of the value chain have been scrutinized to cut unnecessary cost without sacrificing quality. The result is car offering a standard of fittings normally seen on a BMW 735iL or Mercedes 560SEC, yet a considerable lower price (Chernatony 1993).

The seventh is legal protection. Recently, the legal environment is making life more difficult for counter feathers. The European Customs Code allows officials to impound brands suspected of infringing registered trademarks; in Britain search and seize orders can be obtained within hours of suspect goods entering the country (Chernatorny 1993). A firm must obey the US law then developing a new product. A Company cannot make its product 'illegally similar' to another company's established product. An example is Polaroid's successful suit to prevent Kodak from selling its new 
instant picture camera on the grounds that the infringed on Polaroid's instant camera parent (Kotler 1994). Furthermore, Some companies have attempted to be more proactive by turning a threat into a marketing opportunity. For example, Caterpillar employed and ads using the theme that deciding to buy a non-genuine part for your Caterpillar is like rolling dice. The purpose of the ads was to remained buyers why they should stay loyal to the brand (Chernatony 1993).

\section{CONCLUSION}

In conclusion, research suggests that an increase of market share is related to improved brand loyalty. The larger the number of loyal customers, the more stable the larger the brand's market share. Thus, brand loyalty becomes a challenging goal each marketer seeks to attain. However, in the recent decade, because of rapidly changing business environment, most companies have had an apparent decrease in brand loyalty and suffered business decline. Evidence shows that the decline in brand loyalty during this decade is influenced by customers of the 1990's having become much more savvy and price conscious. In the marketplace, on the other hand, the more established companies provide the more brand offerings. Yet, some brands are obviously more dominant than others, there must be no such thing single brand. Hence, every company must urgently and critically rethink their marketing strategy in terms of having strong brand loyalty.

In order to meet customers to wards brand loyalty in today's turbulent competitive business world, marketer must determine a strategy how to develop and to reinforce brand royalty. To develop brand loyalty, Eisman (1990) suggests that a company needs to be concerned in he ways of understanding the customers; keeping brand image consistent; running promotions that develop loyalty, maintaining high standards of customer service; soliciting retailer participation; and Walter \& Bergiel (1989) add one point, making a satisfactory product.

In addition, Chernatony (1993) determines seven types to reinforce brand loyalty by building blocks of brand. The first of which is functional capability which offers consumers the assurance of consistently high quality; the second is symbolism which draws on the right statement for their consumers; the third is the name of the brand which must allow for the possibility of extension into new areas; fourth is linking the brand name with the ownership of a parent company which has a high public profile; the fifth is called shorthand notation through associating their brand names with a few key attributes of the products; the sixth is strategic direction which gives a brand the ability to out perform competitors; and the seventh is legal protection which makes life more difficult for counterfeiters. 


\section{REFERENCES}

Assael, H. 1992, Consumer Behavior \& Marketing Action, $4^{\text {th }}$ Edn., PWSKENT Publishing, Boston.

Caudron, S. 1993, "Brand Loyalty, Can It Be Revived?" Industry Week, Vol. 242, Iss. 7, April pp. 11-14.

Chernatony, L.D. 1993, "The Seven Building Blocks of Brands," Management Today, March, pp.60-68.

Chrispell, D. \& Branderberg, K. 1993, "What's In A Brand?" American Demographic, Vol. 15, Iss. 5, May, pp. 26-32.

Eisman, R. 1990, "Building Brand Loyalty", Incentive Marketing, Vol. 164, Iss. 9, September, pp.39-45.

Exter, T. 1988, "Looking For Brand Loyalty, American Demographic, April, pp. 52-56.

Jacoby, J. \& Chestnut, R.W. 1978, Brand Loyalty Measurement and Management, John Wiley \& Sons, Brisbane. Kotler, P. 1994, Marketing Management, Analysis, Planning, Implementation and Control, $8^{\text {th }}$ Edn. Hall, Sydney.

Johnson, T. 1984, "The Myth of Declining Brand Loyalty," Journal of Advertising Research, Vol.24, No. 1, February-March, pp.9-18.

Loudon, D \& Bitta, A.J.D. 1993, Consumer Behavior, Concepts and Applications, $4^{\text {th }}$ Edn, McGraw-Hill, Sydney.

Mannering, F. \& Winston, C. 1991, "Brand Loyalty and the Decline of American Automobile Firms", Brooking Instution, California.

Mowen, J.C. 1995, Consumer Behavior, $4^{\text {th }}$, Edn, Prentice-Hall, Sydney.

Pierce II, J.A. \& Robinson Jr, R.B. 1994, Strategist Management, Formulation, Implementation, And Control, $5^{\text {th }}$, Edn, Richard Irwin, Sydney.

Robinson, J. 1979, "Brand Strength Means More Than Market Share" Journal of Advertising Research, Vol. 19, No. 5, October, pp.83-87.

Sellers, P. 1993, "Brand, It's Thrive or Die", Fortune, Vol. 128, Iss. 4, August, pp. 52-56.

Weinstein, S. 1993, "The New Brand Loyalty", Progressive Grocer, Vol. 72, Iss. 7, July, pp. 92-100.

Walters, C.G. \& Bergiel, B.J. 1989, Consumer Behavior, South Western Publishing, Ohio. 